\title{
Quiste Radicular (periapical)
}

Florencia Stivanello ${ }^{1}$, Ramiro Alejandro Tomasi ${ }^{1}$, and Lucia Echave Barrios ${ }^{1}$

${ }^{1}$ Affiliation not available

September 12, 2020

\section{Hosted file}

Quiste Radicular (periapical).pdf available at https://authorea.com/users/351629/articles/ 480094-quiste-radicular-periapical 